\title{
Evaluation of the Outcome of the Use of $2 \%$ Lidocaine Irrigation in the Prevention of Abdominal Surgical Site Infection
}

\author{
Ahmed M. Ghanem*, Mustafa Abou-Ali, Ahmed H. Hussein, Ahmed M. \\ Anwar, and Sameh T. Abu-Elela
}

Department of Surgery, Faculty of Medicine, Suez Canal University Hospitals and Medical School, Ismailia, Egypt

\begin{abstract}
Background: Surgical site infection ( $\mathrm{SSI}$ ) is the third most common nosocomial infection, associated with higher morbidity and mortality rates as well as increased cost and prolonged hospital stay for patients. Lidocaine, in addition to being a readily available and accessible local anesthetic, has shown antimicrobial and fungicidal activity. Objectives: Assessing the outcome of using $2 \%$ lidocaine irrigation in the prevention of abdominal SSI in grade II (clean-contaminated), Grade III (contaminated) wounds. Subjects and Methods: This prospective randomized clinical trial included patients who underwent elective and emergency abdominal surgeries in the Department of General Surgery at Suez Canal University Hospitals. The participants were randomly divided in two groups: A study group, who received sterile saline plus Lidocaine $2 \%$. And a control group, who received sterile saline only to compare the 30-day postoperative infection outcomes among them. Results: $56.8 \%$ of participants were males. The mean age of participants was $48.88 \pm 10.18$ years. The study group patients had statistically significant lower incidents of SSI than the control group ( $p=0.03$ ). The overall incidence of SSI was $38.6 \%$. The most prevalent sign of the SSI was pus in $35.3 \%$ and in $76.5 \%$ of the patients' SSI lasted for two weeks. There was no statistically significant difference between both groups regarding their hospital stay duration, laboratory measures, and other postoperative complications. Conclusions: $2 \%$ lidocaine application before skin closure in grade II and grade III wounds decreased the incidence of SSI) in patients undergoing abdominal surgery.
\end{abstract}

Keywords: Surgical site infection (SSI), lidocaine, prevention

\section{Introduction}

Surgical site infection (SSI) is considered the third most common nosocomial infection as it occurs in $5 \%$ to $16 \%$ of hospitalized patients and is more common in patients undergoing colon/rectal surgery. It is associated with higher morbidity and mortality rates (2to 11 -fold risk of death) in addition to increased cost and prolonged hospital stay for patients ${ }^{(1)}$. In most SSI, the source of pathogens is endogenous, originating from the natural flora of the skin, mucous membranes, or hollow 
viscera of the patient. The pathogen most frequently isolated is Staphylococcus aureus, followed by coagulasenegative staphylococci, Escherichia coli, and Pseudomonas aeruginosa. However, abdominal surgery-related SSIs have a more frequent incidence of Escherichia coli $(18.6 \%)$, followed by Staphylococcus aureus (12.7\%), Enteroccus faecalis (7.8\%), coagulase-negative staphylococci (6.4\%), and Pseudomonas aeruginosa $(6.1 \%)^{(2)}$. The influence of different patient, and environmental variables such as patient age, nutritional status, laboratory values, comorbidities, antiseptic techniques and solutions used, type of surgery performed, region and system of the body involved, duration of surgery, operating room ventilation, and adequate sterilization of instruments increase the risk for SSI. Due to changes and developments in medicine aimed at performing more outpatient surgeries and enabling shorter hospital stays, SSI surveillance and monitoring has become more complex(3). The degree of surgical site (SS) contamination classifications was initially developed by the American College of Surgeons and then adapted by the Centers for Disease Control and Prevention (CDC) in 1985; currently, a globally accepted consensus classifies SS as Grade I (clean), Grade II (cleancontaminated), Grade III (contaminated), and Grade IV (dirty/infected)(4). Various techniques and solutions have been implemented for irrigation purposes to prevent and avoid the formation of abscesses and infection of tissues and cavities in contaminated SSs (e.g., grades II to IV) ${ }^{(5)}$. A nosocomial infection rate of 9.0\% among almost 8000 patients was reported in a 1-year prospective surveillance study conducted in a general hospital(6). Vilar-Compte et al(7) performed an 18-month prospective study involving 3372 surgeries performed at the
National Cancer Institute in Mexico and reported a general SSI incidence of up to 9.28\% for grades I through IV (7.35\%, $10.5 \%, 17.3 \%$, and $21.5 \%$, respectively). Of these, $27.16 \%$ were diagnosed during the hospital stay and $72.84 \%$ after hospital discharge $^{(7)}$. Lidocaine was shown to provide analgesia, by blocking both peripheral and central voltage-dependent sodium channels which results in halting the pain impulse initiation and transmission process in the axons. It is generally safe to use topical lidocaine for anesthesia, and adverse reactions are rare. Minor side effects include flushing, redness of the skin, metallic taste and tinnitus $^{(8)}$. Golzari et al. ${ }^{(9)}$ have demonstrated the antimicrobial and fungicidal activity of local anesthetics and the molecular and cellular mechanisms involved. They have shown an excessive inflammatory response and a decrease in the incidence of SSI when antimicrobials are provided $(9)$. In a randomized clinical trial done by Aritzi Galnares et al ${ }^{(10)}$ in the general surgical unit of a Mexican hospital comparing wound irrigation with $2 \%$ lidocaine versus saline solution among 116 patients from a rural clinic, noted a decrease in the frequency of SSI in grade II and grade III wounds. They reported an SSI incidence of $12 \%$ (14 patients) in the saline group versus none in the lidocaine group. Therefore, the current study aimed to assess the outcome of use of $2 \%$ lidocaine irrigation in prevention of abdominal surgical site infection in grade II (clean-contaminated), Grade III (contaminated) wounds.

\section{Patients and Methods}

This prospective randomized clinical trial included patients who underwent elective and emergency abdominal surgeries in the department of General Surgery at Suez Canal University Hospitals over 2019, 2020. On 11/5/2018 
The Medical Ethical Committee of Faculty of Medicine, Suez Canal University approved the study before commencement, and informed consents were obtained from every enrolled patient.

\section{Patients}

The study included 44 Patients their age ranged between 18 to 60 years. 56\% of them were males. The patients underwent elective, and emergency abdominal surgery conducted in the department of General Surgery, with ASA score (I, II) and had grade II (clean-contaminated), Grade III (contaminated) wounds. The study participants were divided in two groups by simple random method: group A, who received sterile saline plus lidocaine $2 \%$ and group $B$, who received sterile saline only to compare the 30-day postoperative infection outcomes among them. Inclusion criteria included patients aged 18 to 60 years, patients ASA (I, II), and patients with grade II (cleancontaminated), grade III (contaminated) wounds. While exclusion criteria included patients aged less than 18 or over 60 years and patients ASA (III, IV).

\section{Procedure}

The study group received subcutaneous tissue irrigation with $100 \mathrm{~mL}$ of $0.9 \%$ saline solution after aponeurotic closure followed by subcutaneous tissue and skin irrigation with $10 \mathrm{~mL} 2 \%$ lidocaine, while the control group had subcutaneous tissue irrigation with $100 \mathrm{~mL}$ of $0.9 \%$ saline solution after aponeurotic closure only, no subcutaneous drain was inserted in both groups. All other procedures, including methods of wound closure, dressing, date of first dressing removal, procedure of cleansing, etc. were standardized to prevent discrepancies. All patients were subjected to history taking including age, brief medical history, type of surgery and wound classification, clinical examination and laboratory investigations as hemoglobin, creatinine, and albumin. Patients were assessed daily during their hospital stay and followed up for 30 days for evidence of SSI based on clinical examination, wound classification. All patients were observed for: delayed wound healing (i.e., wounds required $>7$ days for complete healing, wound inflammation and contamination), Wound abscess (i.e., presence collection of pus that has built up within the tissue of the body, wound dehiscence which means that breaking open of the surgical incision along the suture, and burst abdomen is considered present, when intestine, omentum or other viscera were seen in the abdominal wound.

\section{Statistical Analysis}

Data were analyzed using IBM Statistical Package for Social Sciences software (SPSS), $20^{\text {th }}$ version. Continuous data were presented as mean \pm standard deviation and categorical data as frequencies and percentages. Independent $t$ test/Mann Whitney $U$ test were used to compare between quantitative data as appropriate, while Chi-square/ Fisher Exact was used to compare between the qualitative data as appropriate. Results were considered statistically significant at a $\mathrm{p}$-value $<0.05$ and highly significant at $\mathrm{p}$-value $<0.01$.

\section{Results}

The baseline characteristics of the enrolled patients are shown in Table 1. The mean age of the participants in both groups was $48.8 \pm 10.18$ years. Half of the patients had a history of chronic diseases that were equally distributed between both groups. It was found that there was no statistically significant difference between lidocaine group and saline group in any of baseline characteristics. 


\begin{tabular}{|c|c|c|c|c|}
\hline \multicolumn{5}{|c|}{ ble 1. Clinical characteristics of the studied sample } \\
\hline \multirow[b]{2}{*}{ Clinical characteristics } & \multirow[b]{2}{*}{$\begin{array}{l}\text { Total } \\
(n=44)\end{array}$} & \multicolumn{2}{|c|}{ Study groups } & \multirow[b]{2}{*}{$\begin{array}{c}\mathrm{p}- \\
\text { value }\end{array}$} \\
\hline & & $\begin{array}{c}\text { Lidocaine } \\
\text { group } \\
(n=22)\end{array}$ & $\begin{array}{l}\text { Saline } \\
\text { group } \\
(n=22)\end{array}$ & \\
\hline Age (years), mean \pm SD & $\begin{array}{c}48.88 \pm \\
10.18\end{array}$ & $48.95 \pm 8.49$ & $\begin{array}{c}48.12 \pm \\
11.06\end{array}$ & $0.96^{a}$ \\
\hline $\begin{array}{l}\text { Gender, n (\%) } \\
\text { Male } \\
\text { Female }\end{array}$ & $\begin{array}{l}25(56.8) \\
19(43.2)\end{array}$ & $\begin{array}{l}12(54.5) \\
10(45.5)\end{array}$ & $\begin{array}{l}13(59.1) \\
9(40.9)\end{array}$ & $0.76^{b}$ \\
\hline $\begin{array}{l}\text { BMI }\left(\mathrm{kg} / \mathrm{m}^{2}\right), \mathrm{n}(\%) \\
\text { Normal weight } \\
\text { Overweight } \\
\text { Obese }\end{array}$ & $\begin{array}{l}15(34.1) \\
15(34.1) \\
14(31.8)\end{array}$ & $\begin{array}{l}6(27.3) \\
9(40.9) \\
7(31.8)\end{array}$ & $\begin{array}{l}9(40.9) \\
6(27.3) \\
7(31.8)\end{array}$ & $0.54^{b}$ \\
\hline $\begin{array}{c}\text { Smoking, n (\%) } \\
\text { Present } \\
\text { Absent }\end{array}$ & $\begin{array}{l}18(27.3) \\
26(59.1)\end{array}$ & $\begin{array}{c}6(27.3) \\
16(72.7)\end{array}$ & $\begin{array}{l}12(54.5) \\
10(45.5)\end{array}$ & $0.06^{b}$ \\
\hline $\begin{array}{l}\text { Chronic illness, } \mathrm{n}(\%) \\
\text { Absent } \\
\text { Present } \\
\text { - Hypertension } \\
\text { - Chronic renal disease } \\
\text { - Diabetes mellitus }\end{array}$ & $\begin{array}{c}22(50) \\
22(50) \\
11(25) \\
4(9.1) \\
16(36.4)\end{array}$ & $\begin{array}{c}10(45.5) \\
12(54.5) \\
6(27.3) \\
2(9.1) \\
8(36.4)\end{array}$ & $\begin{array}{c}12(54.5) \\
10(45.5) \\
5(22.7) \\
2(9.1) \\
8(36.4)\end{array}$ & $0.54^{b}$ \\
\hline
\end{tabular}

${ }^{a} \mathrm{p}$-values are based on Mann Whitney $\mathrm{U}$ test. Statistical significance at $\mathrm{P}<0.05$

${ }^{\mathrm{b}} \mathrm{p}$-values are based on Chi-square test. Statistical significance at $\mathrm{P}<0.05$

The total number of elective operations was 14 patients $(31.8 \%)$ while the total number of emergency operations was 30 patients (68.2\%) The clinical characteristics of diabetic patients are shown in Table 2. There was no statistically significant difference between lidocaine group and saline group in their diabetes duration $(p=0.32), \operatorname{HbA} 1 c(p=0.161)$ or presence of complications $(p=0.90)$. In Lidocaine group, four patients had previous history of amputations, whereas in saline group four patients had history of diabetic retinopathy. Table 3 shows the clinical characteristics of patients on steroid therapy, where two patients were in Lidocaine group, whereas four patients belonged to saline group, with no history of neoadjuvasnt chemotherapy. It was found that there was no statistically significant difference between lidocaine group and saline group in the type of abdominal surgery $(p=0.19)$, history of operation $(p=0.90)$ or history of surgical site infection $(p=0.90)$ (Table 4$)$. There was no statistically significant difference between lidocaine group and saline group in their operative time $(p=0.073)$, grade of wound contamination $(p=0.36)$ or antibiotic prophylaxis $(\mathrm{p}=0.45)$ (Table 5$)$. Table 6 shows that patients at Lidocaine group had statistically significant lower incidents of surgical site infection (SSI) than patients at saline group $(p=0.03)$. 


\begin{tabular}{|c|c|c|c|c|}
\hline \multirow[b]{2}{*}{ Clinical characteristics } & \multirow{2}{*}{$\begin{array}{l}\text { Total } \\
(n=16)\end{array}$} & \multicolumn{2}{|c|}{ Study groups } & \multirow[b]{2}{*}{ p-value } \\
\hline & & $\begin{array}{l}\text { Lidocaine group } \\
\qquad(n=8)\end{array}$ & $\begin{array}{l}\text { Saline group } \\
\qquad(n=8)\end{array}$ & \\
\hline \multicolumn{5}{|l|}{ Duration of diabetes, $\mathrm{n}(\%)$} \\
\hline$<10$ years & $7(43.8)$ & $5(62.5)$ & $2(25)$ & \multirow{2}{*}{$0.32^{a}$} \\
\hline$>10$ years & $9(56.3)$ & $3(37.5)$ & $6(75)$ & \\
\hline HBA1c (\%), mean \pm SD & $9.7 \pm 1.29$ & $10.21 \pm 1.52$ & $9.18 \pm 0.82$ & $0.16^{b}$ \\
\hline \multicolumn{5}{|l|}{ Complications, n (\%) } \\
\hline Absent & $7(43.8)$ & $4(50)$ & $3(37.5)$ & \multirow{4}{*}{$0.90^{a}$} \\
\hline Present & $9(56.3)$ & $4(50)$ & $5(62.5)$ & \\
\hline - Amputation & $5(31.3)$ & $4(50)$ & $1(12.5)$ & \\
\hline - Retinopathy & $4(25)$ & 0 & $4(50)$ & \\
\hline
\end{tabular}

${ }^{a} \mathrm{p}$-values are based on Fisher's Exact test. Statistical significance at $\mathrm{P}<0.05$

${ }^{b} \mathrm{p}$-values are based on Mann Whitney $\mathrm{U}$ test. Statistical significance at $\mathrm{P}<0.05$

The overall incidence of SSI was (38.6\%) of all patients, $(22.5 \%)$ of patients in lidocaine group had SSI while (54.5\%) of saline group had SSI. The most prevalent sign of the SSI was infected seroma (35.3\%) while in $76.5 \%$ of the patients surgical site infection lasted for two weeks. There was no statistically significant difference between lidocaine group and saline group in their hospital stay duration $(p=0.57)$.

\begin{tabular}{|c|c|c|c|c|}
\hline \multirow[b]{3}{*}{ Clinical characteristics } & \multirow{3}{*}{$\begin{array}{l}\text { Total } \\
\mathrm{n}(\%) \\
(\mathrm{n}=44)\end{array}$} & \multirow{2}{*}{\multicolumn{2}{|c|}{ Study groups, n (\%) }} & \multirow[b]{3}{*}{ p-value } \\
\hline & & & & \\
\hline & & $\begin{array}{l}\text { Lidocaine group } \\
\quad(n=22)\end{array}$ & $\begin{array}{l}\text { Saline group } \\
(n=22)\end{array}$ & \\
\hline \multicolumn{5}{|l|}{ History of steroid treatment } \\
\hline Absent & $38(86.4)$ & $20(90.9)$ & $18(81.8)$ & \multirow{2}{*}{$0.66^{a}$} \\
\hline Present & $6(13.6)$ & $2(9.1)$ & $4(18.2)$ & \\
\hline \multicolumn{5}{|l|}{ Last steroid therapy $(n=6)$} \\
\hline Within last 2 month & $2(33.3)$ & 0 & $2(50)$ & $017^{a}$ \\
\hline Within last 6 month & $4(66.7)$ & $2(100)$ & $2(50)$ & 0.47 \\
\hline
\end{tabular}

${ }^{a} \mathrm{p}$-values are based on Fisher's Exact test. Statistical significance at $\mathrm{P}<0.05$

Table 7 shows that there was no statistically significant difference between lidocaine group and saline group regarding their laboratory measures among patients with positive or negative SSI. There was no predominant type of bacterial growth presented in the infected surgical wounds among lidocaine group: staph aures (20\%), enterobacteria (20\%), E. coli (20\%), pseudomonas (20\%) and MRSA (20\%). While among saline group (37\%) of surgical site infections had staph aureus growth and (27\%) of them had pneumococci growth. The most frequently resistant antibiotic among lidocaine group was oxacillin (40\%). 
Antibiotics resistance among saline group was $87 \%$ to ceftriaxone and $13 \%$ of them was resistant to penicillin. Table 8 shows that there was no statistically significant difference between lidocaine group and saline group regarding postoperative complications $(p=0.12)$ and signs of septic $\operatorname{shock}(p=0.122)$.

\begin{tabular}{|c|c|c|c|c|}
\hline Table 4. Preop & rative chal & acteristics of patic & nts $(n=44)$ & \\
\hline \multirow[b]{2}{*}{ Clinical characteristics } & \multirow{2}{*}{$\begin{array}{c}\text { Total } \\
n(\%) \\
(n=44)\end{array}$} & \multicolumn{2}{|c|}{ Study groups, $\mathbf{n}(\%)$} & \multirow[b]{2}{*}{$p$-value } \\
\hline & & $\begin{array}{l}\text { Lidocaine group } \\
\quad(n=22)\end{array}$ & $\begin{array}{l}\text { Saline group } \\
\quad(n=22)\end{array}$ & \\
\hline \multicolumn{4}{|l|}{ ASA classification } & \multirow{5}{*}{$0.13^{a}$} \\
\hline 1 & $11(25)$ & $6(27 \cdot 3)$ & $5(22.7)$ & \\
\hline 2 & $12(27 \cdot 3)$ & $3(13.6)$ & $9(40.9)$ & \\
\hline 3 & $15(34.1)$ & $8(36.4)$ & $7(31.8)$ & \\
\hline 4 & $6(13.6)$ & $5(22.7)$ & $1(4.5)$ & \\
\hline \multicolumn{2}{|l|}{ Type of abdominal surgery } & & & \multirow{3}{*}{$0.19^{b}$} \\
\hline Emergency & $30(68.2)$ & $17(77 \cdot 3)$ & $13(59.1)$ & \\
\hline Elective & $14(31.8)$ & $5(22.7)$ & $9(40.9)$ & \\
\hline \multirow{3}{*}{$\begin{array}{l}\text { History of SSI } \\
\text { Absent } \\
\text { Present }\end{array}$} & & & & \multirow{3}{*}{$0.90^{a}$} \\
\hline & $37(84.1)$ & $18(81.8)$ & $19(86.4)$ & \\
\hline & $7(15.9)$ & $4(18.2)$ & $3(16.3)$ & \\
\hline
\end{tabular}

${ }^{a} \mathrm{p}$-values are based on Fisher's Exact test. Statistical significance at $\mathrm{P}<0.05$

${ }^{\mathrm{b}} \mathrm{p}$-values are based on Chi-square test. Statistical significance at $\mathrm{P}<0.05$

\section{Discussion}

Review studies of clinical trials for diverse commercial antiseptic solutions for wound irrigation have proven they are effective in eradicating bacteria, fungi, and viruses, significantly decreasing the rate of SSIs. Specifically, Lidocaine, in addition to being a readily available and accessible local anesthetic, is known to have bacteriostatic properties. Its proven effectiveness may impact SSI if used for SS irrigation before closure in addition to prophylactic and therapeutic antibiotic therapy ${ }^{(11)}$. The study included patients who experienced any type of abdominal surgery, and it was found that patients at Lidocaine group had statistically significant lower incidents of SSI than patients at saline group where the most prevalent sign of the SSI was infected seroma. Though, there was no statistically significant difference between lidocaine group and saline group in their hospital stay duration, laboratory measures and other postoperative complications. Throughout the study, it was found that there was a statistically significant difference in the incidence of SSI regarding the period of diabetes in diabetic patients, HbA1c or presence of complications. Different experimental and case studies have shown comorbidities such as diabetes mellitus and obesity increase the risk of complications ${ }^{(12,13)}$. Another study found diabetes to be a significant contributor to the risk of SSIs, potentially beyond its role in causing hyperglycemia during or after surgery ${ }^{(14)}$. Furthermore, the occurrence of peri- 
operative hyperglycemia and subsequent immune suppression is affected by the complex contributions of factors in addition to the diabetic history of the patient, including physiologic stressors and exogenous glucose administration (15).

\begin{tabular}{|c|c|c|c|c|}
\hline \multirow[b]{3}{*}{ Clinical characteristics } & \multirow{3}{*}{$\begin{array}{c}\text { Total } \\
\mathrm{n}(\%) \\
(\mathrm{n}=44)\end{array}$} & 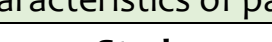 & s & \\
\hline & & \multicolumn{2}{|c|}{ Study groups, n (\%) } & \multirow[b]{2}{*}{$\mathrm{p}$-value } \\
\hline & & $\begin{array}{l}\text { Lidocaine group } \\
\qquad(\mathrm{n}=22)\end{array}$ & $\begin{array}{l}\text { Saline group } \\
(n=22)\end{array}$ & \\
\hline \multicolumn{5}{|l|}{ Operative time } \\
\hline$<1.5$ hours & $14(31.8)$ & $4(18.2)$ & $10(45 \cdot 5)$ & \multirow{3}{*}{$0.073^{a}$} \\
\hline $1.5-4$ hours & $19(43.2)$ & $13(59.1)$ & $6(27.3)$ & \\
\hline$>4$ hours & $11(25)$ & $2(22.7)$ & $6(27.3)$ & \\
\hline \multicolumn{5}{|l|}{ Wound contamination } \\
\hline II & $23(52.3)$ & $13(59.1)$ & $10(45 \cdot 5)$ & \multirow{2}{*}{$0.36^{a}$} \\
\hline III & $21(47.7)$ & $9(40.9)$ & $12(54 \cdot 5)$ & \\
\hline \multicolumn{5}{|l|}{ Antibiotic prophylaxis } \\
\hline Absent & $9(20.5)$ & $3(13.6)$ & $6(27 \cdot 3)$ & \multirow{2}{*}{$0.45^{b}$} \\
\hline Present & $35(79.5)$ & $19(86.4)$ & $16(72.7)$ & \\
\hline \multicolumn{5}{|l|}{ Drain application } \\
\hline Absent & $16(36.4)$ & $6(27.3)$ & $10(45.5)$ & \multirow{2}{*}{$0.21^{\mathrm{a}}$} \\
\hline Present & $28(63.6)$ & $16(72.7)$ & $12(54.5)$ & \\
\hline
\end{tabular}

${ }^{a} \mathrm{p}$-values are based on Chi-square test. Statistical significance at $\mathrm{P}<0.05$

${ }^{\mathrm{b}} \mathrm{p}$-values are based on Fisher's Exact test. Statistical significance at $\mathrm{P}<0.05$

Other published reports have demonstrated that patients with diabetes are more susceptible to wound infection because of impaired neutrophil chemotaxis and phagocytosis ${ }^{(16)}$. Although in our study there was no statistical difference regarding the age and chronic diseases among patients in both groups, as their mean age was about 48 years, but in Cheng et al survey, they found an association between the age of surgical patients and SSI, suggesting that patients aged over 75 years (5.6\%) were more likely to develop SSI than those under the age of 75 years (3.0\%). This lack of a significant association may be because elderly patients with chronic underlying disease often have decreased physiological defense mechanisms and poorer immune function. Therefore, elderly patients should undergo elective surgery when their bodies are in good condition ${ }^{(17)}$. Regarding the steroid therapy, only two patients were in Lidocaine group, whereas four patients belonged to saline group. Use of steroids has been linked to the risk of SSI, although it is important to note that the underlying reason for which the patient is on steroid treatment may by itself increase the risk of SSI ${ }^{(18)}$. In a review performed to assess the adverse side effects of dexamethasone in surgical patients, it was found that infection rates differed between studies, ranging from $0 \%$ to $18 \%$ and reflecting the different surgical populations ${ }^{(19)}$. Regarding the pre- and 
intra-operative assessment, it was found that there was no statistically significant difference between lidocaine group and saline group in the type of abdominal surgery (elective versus emergency), history of operation or history of surgical site infection and ASA score, grade of wound contamination or antibiotic prophylaxis. According to a cohort study by Michelson et al ( $N=2400$ surgeries), alcohol consumption and American
Society of Anesthesiologists (ASA) score, and surgery location were considered SSI risk factors(3). Regarding the type of surgery specifically elective surgeries were associated with lower incidence of SSI when compared to emergent surgeries which is comparable to results found by Cheng et al, found that the incidence of SSI in emergency surgery cases was higher than in elective surgery cases.

\begin{tabular}{|c|c|c|c|c|}
\hline \multirow[b]{2}{*}{ Variables } & \multirow{2}{*}{$\begin{array}{l}\text { Total } \\
(n=44)\end{array}$} & \multicolumn{2}{|c|}{ Study groups } & \multirow[b]{2}{*}{ p-value } \\
\hline & & $\begin{array}{l}\text { Lidocaine group } \\
\qquad(n=22)\end{array}$ & $\begin{array}{l}\text { Saline group } \\
\quad(n=22)\end{array}$ & \\
\hline $\begin{array}{l}\text { Development of SSI, n (\%) } \\
\text { No } \\
\text { Yes }\end{array}$ & $\begin{array}{l}27(61.4) \\
17(38.6)\end{array}$ & $\begin{array}{c}17(77.3) \\
5(22.5)\end{array}$ & $\begin{array}{l}10(45.5) \\
12(54.5)\end{array}$ & $0.03^{a}$ \\
\hline $\begin{array}{l}\text { Signs of SSI } \\
\text { Redness/hotness } \\
\text { Seroma } \\
\text { Infected seroma } \\
\text { Abscess }\end{array}$ & $\begin{array}{l}4(23.5) \\
3(17.6) \\
6(35.3) \\
4(23.5)\end{array}$ & $\begin{array}{l}1(20) \\
1(20) \\
2(40) \\
1(20)\end{array}$ & $\begin{array}{c}3(25) \\
2(16.7) \\
4(33.3) \\
3(25)\end{array}$ & $0.90^{b}$ \\
\hline $\begin{array}{l}\text { Time of SSI } \\
\text { Within } 2 \text { days } \\
\text { Within } 2 \text { weeks } \\
\text { After } 2 \text { weeks }\end{array}$ & $\begin{array}{c}3(17.6) \\
13(76.5) \\
1(5.9)\end{array}$ & $\begin{array}{c}1(20) \\
4(80) \\
0\end{array}$ & $\begin{array}{l}2(16.7) \\
9(75) \\
1(8.3)\end{array}$ & $0.90^{b}$ \\
\hline Hospital stay (days), mean \pm SD & $4.41 \pm 2.56$ & $4.4 \pm 2.98$ & $4.39 \pm 2.13$ & $0.57^{c}$ \\
\hline
\end{tabular}

${ }^{a} \mathrm{p}$-values are based on Chi-square test. Statistical significance at $\mathrm{P}<0.05$

${ }^{b} \mathrm{p}$-values are based on Fisher's Exact test. Statistical significance at $\mathrm{P}<0.05$

c $\mathrm{p}$-values are based on Mann Whitney $U$ test. Statistical significance at $P<0.05$

This is because Emergency operative procedures do not allow for the standard preoperative preparation normally done within a facility for a scheduled operation (e.g. confirmation of stable vital signs, adequate antiseptic skin preparation, and decontamination of the colon in advance of colon surgery) and patients with acute abdominal pain account for the majority of emergency surgeries, and are at high perioperative risk for SSI because of the infected operation, especially at the preoperative infection lesions ${ }^{(17)}$. Previous abdominal surgery has been shown to be associated with increased risk of any SSI, including deep or organ space infections. For superficial SSIs, it is thought that the decreased vascularity of the prior scar and inherent problems related to prior wound healing complications may be the principle factors involved ${ }^{(18)}$. Regarding the incidence of SSI presence, it was 
found that patients at Lidocaine group had statistically significant lower incidents of surgical site infection (SSI) than patients at saline group. That was similar in a study performed by Quiroga-Garza et al. Study, where a total of 84 patients, 39 in the control and 45 in the experimental group were obtained, demonstrated that patients who received irrigation with 10 $\mathrm{mL}$ of $2 \%$ lidocaine, in addition to the standard intravenous antibiotics, had a lower SSI rate than those who did not ${ }^{(11)}$. That was also confirmed by Noriega-Salas et al. who assessed 11 patients in the $2 \%$ lidocaine group and 11 in the control group and found that No infection was observed in the 11 patients in whom $2 \%$ lidocaine had been applied, whereas 3 patients from the $0.9 \%$ saline solution group presented infection of the surgical wound, with a statistically significant difference between both groups ${ }^{(20)}$.

\begin{tabular}{|c|c|c|c|c|}
\hline \multirow{2}{*}{ Variables } & \multirow{2}{*}{$\begin{array}{c}\text { Total } \\
\text { mean } \pm \text { SD }\end{array}$} & \multicolumn{2}{|c|}{$\begin{array}{c}\text { Study groups } \\
\text { mean } \pm \text { SD }\end{array}$} & \multirow{2}{*}{ p-value } \\
\hline & & Lidocaine group & Saline group & \\
\hline \multicolumn{5}{|l|}{ Among patient with negative SSI $(n=27)$} \\
\hline $\operatorname{TLC}\left(\times 10^{3} / \mathrm{cmm}\right)$ & $9.15 \pm 1.92$ & $9 \cdot 37 \pm 2.17$ & $8.76 \pm 1.42$ & $0.61^{a}$ \\
\hline Albumin (g/dL) & $4.32 \pm 4.17$ & $4.69 \pm 5.27$ & $3.70 \pm 0.28$ & $0.44^{a}$ \\
\hline Serum creat $(\mathrm{mg} / \mathrm{dL})$ & $1.28 \pm 0.68$ & $1.47 \pm 0.79$ & $0.97 \pm 0.14$ & $0.13^{\mathrm{a}}$ \\
\hline $\mathrm{RBS}(\mathrm{mg} / \mathrm{dL})$ & $154.2 \pm 71.8$ & $154.94 \pm 58.92$ & $153 \pm 93.37$ & $0.57^{\mathrm{a}}$ \\
\hline \multicolumn{5}{|l|}{ Among patient with positive SSI $(n=17)$} \\
\hline $\operatorname{TLC}\left(\times 10^{3} / \mathrm{cmm}\right)$ & $16.55 \pm 5.79$ & $17.24 \pm 6.13$ & $162.66 \pm 5.91$ & $0.57^{\mathrm{a}}$ \\
\hline Albumin (g/dL) & $2.91 \pm 0.65$ & $2.70 \pm 0.48$ & $2.99 \pm 0.71$ & $0.33^{\mathrm{a}}$ \\
\hline Serum creat $(\mathrm{mg} / \mathrm{dL})$ & $1.74 \pm 0.91$ & $1.98 \pm 0.91$ & $1.64 \pm 0.93$ & $0.32^{\mathrm{a}}$ \\
\hline RBS (mg/dL) & $204 \pm 88.58$ & $170.6 \pm 86.54$ & $217.92 \pm 89.29$ & $0.31^{a}$ \\
\hline
\end{tabular}

${ }^{a}$ p-values are based on Mann Whitney $U$ test. Statistical significance at $P<0.05$

However, in a trial performed covering $>9000$ patients to analyze the effect of intraoperative wound infection irrigation (IOWI) with any solution compared to no irrigation revealed a significant benefit in the reduction of SSI rates, and this effect was strongest in colorectal surgery and that IOWI with antibiotic solutions had a stronger effect than irrigation with saline alone $^{(21)}$. The most prevalent sign of the SSI was infected seroma, and the surgical site infection lasted for two weeks in more than half of the patients, though, there was no statistically significant difference between lidocaine group and saline group in their hospital stay duration. In a study performed by Adejumo et al to assess the incidence of SSI in a Nigerian tertiary care center, and it was found that more than $70 \%$ of the surgeries in their study were carried out as emergencies, and about $50 \%$ of the total number of wound infections developed among patients that had laparotomies for peritonitis on emergency basis. Therefore, it could be considered that laparotomies for sepsis are a significant reason for the high incidence of SSI. This could be explained as peritoneal inflammation with an already established infection in those patients could not be reversed before surgical intervention, with contamination 
of the wound margins by purulent exudates during surgical procedures leading to established post-operative infection $^{(22)}$. Moreover, in a study performed by Kusachi et al., they found that the development of SSI after abdominal surgery necessitates extension of hosp-italizetion two-fold and increases the post-operative healthcare expenditure 2.5-fold(23). It was also found that patients who develop SSIs have longer hospital stays and incur higher treatment costs than other patients; in some types of surgery they also have higher mortality rates $^{(24)}$. Moreover, there was no statistically significant difference between lidocaine group and saline group regarding their laboratory measures among patients with positive or negative SSI including Total Leucocytic Count, Albumin, creatinine level and Random Blood Sugar. In Quiroga-Garza et al. Study, it was found that creatinine was not statistically significantly different, but hemoglobin and albumin were significantly different between the study and control groups. Moreover, variables analyzed included creatinine, hemoglobin, and albumin, and results suggested hemoglobin and albumin levels below standardized normal values before surgery increased the incidence of $\mathrm{SSI}^{(11)}$. In a prospective, descriptive, comparative study on 94 patients undergoing surgery, Gunningberg et al. confirmed an albumin level $<3.4 \mathrm{~g} / \mathrm{dL}$ was a predictor for $\mathrm{SSI}^{(25)}$.

\begin{tabular}{|c|c|c|c|c|}
\hline \multirow[b]{2}{*}{ Variables } & \multirow{2}{*}{$\begin{array}{c}\text { Total } \\
\mathrm{n}(\%) \\
(\mathrm{n}=44)\end{array}$} & \multicolumn{2}{|c|}{ Study groups, n (\%) } & \multirow[b]{2}{*}{$\mathrm{p}$-value } \\
\hline & & $\begin{array}{l}\text { Lidocaine group } \\
\qquad(n=22)\end{array}$ & $\begin{array}{l}\text { Saline group } \\
\quad(n=22)\end{array}$ & \\
\hline $\begin{array}{l}\text { Postoperative complications } \\
\text { Absent } \\
\text { Present } \\
\text { - Incisional hernia } \\
\text { - Chest infections } \\
\text { - DVT } \\
\text { - UTI } \\
\text { - Burst Abdomen } \\
\text { - Reoperation }\end{array}$ & $\begin{array}{c}27(61.4) \\
17(38.6) \\
2(4.5) \\
11(25) \\
3(6.8) \\
5(11.4) \\
3(6.8) \\
2(4.5)\end{array}$ & $\begin{array}{c}16(72.7) \\
6(27.3) \\
2(9.1) \\
4(18.2) \\
0 \\
1(4.5) \\
1(4.5) \\
0\end{array}$ & $\begin{array}{c}11(50) \\
11(50) \\
0 \\
7(31.8) \\
3(13.6) \\
4(18.2) \\
2(9.1) \\
2(9.1)\end{array}$ & $0.12^{a}$ \\
\hline $\begin{array}{l}\text { Signs of septic shock } \\
\text { Absent } \\
\text { Present } \\
\text { - Tachypnea } \\
\text { - Tachycardia } \\
\text { - Elevated total leucocytic } \\
\text { - Hypotension } \\
\text { - Hypo/hyperthermia }\end{array}$ & $\begin{array}{c}41(93.2) \\
3(6.8) \\
3(6.8) \\
3(6.8) \\
2(4.5) \\
3(6.8) \\
0\end{array}$ & $\begin{array}{c}21(95.5) \\
1(4.5) \\
1(4.5) \\
1(4.5) \\
1(4.5) \\
1(4.5) \\
0\end{array}$ & $\begin{array}{c}20(90.9) \\
2(9.1) \\
2(9.1) \\
2(9.1) \\
1(4.5) \\
2(9.1) \\
0\end{array}$ & $0.122^{a}$ \\
\hline
\end{tabular}

${ }^{a} \mathrm{p}$-values are based on Chi-square test. Statistical significance at $\mathrm{P}<0.05$ 


\section{Study Limitations}

Limitations of this study include a small sample size and the absence of considering other variables that may affect SSI rates such as anthropometric measurements to assess nutritional status and body mass index, characteristics of the surgery such as emergency versus scheduled surgery, length of the procedure, and need for blood transfusion. The sample size was small and did not include all surgeries to correctly report the SSI incidence. Future studies should take patient history and comorbidities into account and include a larger population to help determine how SSI could benefit from lidocaine irrigation with performing them in different sites to be able to generalize the results throughout the whole population.

\section{Conclusion}

In the light of the present study, it has been proven that saline irrigation followed by $2 \%$ lidocaine application before skin closure in wounds grade II (clean-contaminated) and grade III (contaminated) decreased the incident of surgical site infection (SSI) significantly compared to the saline irrigation only.

\section{References}

1. Awad SS. Adherence to surgical care improvement project measures and post-operative surgical site infections. Surg Infect (Larchmt). 2012;13(4):2347.

2. Hidron Al, Edwards JR, Patel J, Horan TC, Sievert DM, Pollock DA, et al. NHSN annual update: antimicrobialresistant pathogens associated with healthcare-associated infections: annual summary of data reported to the National Healthcare Safety Network at the Centers for Disease
Control and Prevention, 2006-2007. Infect Control Hosp Epidemiol. 2008;29(11):996-1011.

3. Michelson JD, Pariseau JS, Paganelli WC. Assessing surgical site infection risk factors using electronic medical records and text mining. Am J Infect Control. 2014;42(3):333-6.

4. R Chard. Wound classifications. AORN J. 2008;88(1):108-10.

5. Noriega-Salas AL, Sánchez-LópezLópez MÁ, Lorenzana GI SJ. Aplicación de lidocaína simple al $2 \%$ en tejido celular subcutáneo de heridas quirúrgicas limpias-contaminadas y contaminadas para disminuir la incidencia de. Cir Gen;33(3):180-4.

6. Tinoco JC, Pérez-Prado MC. Epidemiología de las infecciones nosocomiales en un hospital de segundo nivel. Salud Publica Mex. 2014;41(1):S44-50.

7. Vilar-Compte D, Sandoval S, P G, M de la R. Vigilancia de las infecciones de herida quirúrgica. Experiencia de 18 meses en el Instituto Nacional de Cancerología. pública de México. 1999;41:S44-50.

8. Bauer LA. Applied clinical pharmacokinetics. Third edition.New York: McGraw Hill Professional Publishing. 2014.

9. Golzari SE, Soleimanpour $\mathrm{H}$, Mahmoodpoor A, Safari S, Ala A. Lidocaine and Pain Management in the Emergency Department: A Review Article. Anesthesiol Pain Med. 2014;3(3):e15444.

10. Aritzi Galnares P, M DZ. Aplicación de lidocaína en el tejido subcutáneo, en un modelo experimental. Cir Gen. 2016;19(2):120-3.

11. Quiroga-Garza A, Valdivia-Balderas JM, Trejo-Sánchez MÁ, Espinosa-Uribe AG, Reyes-Hernández CG, Elizondo-Omaña RE. A Prospective, Randomized, Controlled Clinical Trial to Assess Use of $2 \%$ Lidocaine Irrigation to Prevent Abdominal Surgical Site Infection. Ostomy Wound Manage. 2017; 63 (8): 12-21. 
12. Hirsch T, Spielmann M, Zuhaili B, Koehler T, Fossum M, Steinau $\mathrm{H}-\mathrm{U}$, et al. Enhanced susceptibility to infections in a diabetic wound healing model. BMC Surg. 2008;8(1).

13. Gunawardane DN, Allen PW. Selected Case From the Arkadi M. Rywlin International Pathology Slide. Adv Anat Pathol. 2015;22(6):388-91.

14. Martin ET, Kaye KS, Knott C, Nguyen $H$, Santarossa $M$, Evans $R$, et al. Diabetes and Risk of Surgical Site Infection: A Systematic Review and Meta-analysis. Infect Control Hosp Epidemiol. 2016;37(1):88-99.

15. Russo N. Perioperative Glycemic Control. Anesthesiol Clin. 2012; 30(3): 445-66.

16. Talbot TR. Diabetes mellitus and cardiothoracic surgical site infections. Am J Infect Control. 2005;33(6):353-9.

17. Cheng K, Li J, Kong Q, Wang C, Ye N, Xia G. Risk factors for surgical site infection in a teaching hospital: a prospective study of 1,138 patients. 2015;9:1171-7.

18. Eckhauser F, Azoury S, Farrow N, Hu Q, Soares K, Hicks C, et al. Postoperative abdominal wound infection \&amp;ndash; epidemiology, risk factors, identification, and management. Chronic Wound Care Manag Res. 2015;2:137.

19. Polderman JAW, Farhang-Razi V, van Dieren S, Kranke P, DeVries JH, Hollmann MW, et al. Adverse sideeffects of dexamethasone in surgical patients: an abridged Cochrane systematic review. Anaesthesia. 2019.

20. Noriega-Salas AL, Sánchez-López-
López MÁ, Esperón Lorenzana GI, Trejo Suárez J. Application of $2 \%$ lidocaine on subcutaneous cell tissue of clean-contaminated and contaminated surgical wounds to diminish the incidence of infection. Cir Gen. 2011;33(3):180-4.

21. Mueller TC, Loos $M$, Haller $B$, Mihaljevic AL, Nitsche $U$, Wilhelm $D$, et al. Intra-operative wound irrigation to reduce surgical site infections after abdominal surgery: a systematic review and meta-analysis. Langenbeck's Arch Surg. 2015;400(2):167-81.

22. Adejumo AA, Nuhu M, Afolaranmi $T$. Incidence and risk factors of abdominal surgical site infection in a Nigerian Tertiary Health care centre. Int J Infect Control. 2015;11(4).

23. Kusachi S, Kashimura N, Konishi T, Shimizu J, Kusunoki M, Oka M, et al. Length of Stay and Cost for Surgical Site Infection after Abdominal and Cardiac Surgery in Japanese Hospitals: Multi-Center Surveillance. Surg Infect (Larchmt). 2012;13(4):257-65.

24. Norman G, Atkinson RA, Smith TA, Rowlands C, Rithalia AD, Crosbie EJ, et al. Intracavity lavage and wound irrigation for prevention of surgical site infection. Cochrane database Syst Rev. 2017;10(10):CD012234.

25. Gunningberg L, Persson C, Åkerfeldt T, Stridsberg M, Swenne CL. Pre- and postoperative nutritional status and predictors for surgical-wound infections in elective orthopaedic and thoracic patients. E Spen Eur E J Clin Nutr Metab. 2008;3(3):e93-101. 